\title{
Undiksha Students' Level of Understanding about the Civic Education in Implementation the Socio- Pedagogical, Socio-Academic, and Socio-Cultural Missions in to Create Smart and Good Citizenships
}

\author{
I Wayan Budiarta $^{1}$, A. A. Istri Dewi Adhi Utami ${ }^{2}$ \\ \{iwayan.budiarta0@gmail.com ${ }^{1}$, adhi.utami@undiksha.ac.id² \\ Universitas Pendidikan Ganesha, Indonesia ${ }^{12}$
}

\begin{abstract}
This study aims to explain Undiksha students' level of understanding about the Civic Education essence in carrying out the socio-pedagogical, socio-academic, and socio-cultural missions in to form smart and good citizenships. This study used a survey method by providing a multiple choice (objective test) as the data instrument. The data obtained were analyzed descriptive quantitatively. The results of this study the level of students' understanding about the essence of Civic Education in carrying out the sociopedagogical, socio-academic, and socio-cultural mission to form smart and good Citizenship is at a value of 64.98 , which is classified in the medium range, not in the maximal range yet. The efforts that can be made in order to improve students' understanding about the essence of Civic Education are the implementation of the Civic Education' missions, and empowering students through pedagogical, teaching and learning processes, academic processes, research, study, and public service so that they have civic skills.
\end{abstract}

Keywords: civic education mission; socio-pedagogical; socio-academic; and sociocultural.

\section{Introduction}

Almost all circles agree and it has become a common knowledge, especially among Civic Education academics that the purpose of Civic Education ( $\mathrm{PKn}$ in Indonesia) is to formed good and intelligent citizens, or smart and good citizenship. The general goal of Civic Education is to educating citizens to be good citizens, which can be described as patriotic, tolerant, loyal to the nation and state, religious, democratic, and truly uphold the values of Pancasila [1].

Based on the description about the essence and the vision of Civic Education above; Civic Education have a socio-pedagogical, socio-academic, and socio-cultural mission as follows. Socio-pedagogical mission is obliged to empowering students through education, teaching and training processes so they may have seven civic skills, such as civic knowledge, civic disposition, civic skills, civic confidence, civic commitment, civic competence, and integrated civic culture which integrated in the ability to think, behave and act as Indonesian citizens who have good character and democratic [2]. The social-academic mission, Civic 
Education must be useable for the students to develop a better civic and democratic life academically through various activities of thinking and reflective inquiry on various civic education problems in community, nation and state. In this case civics should be able to be a mean of social reconstruction, or be a social engineering for educators and students in applying the principles of thinking, and scientific research that creates and develops democratic citizenship life with a better character according to the stages of social, emotional, and moral development of the students. Based on the socio-cultural mission, then civics must be useful for educators and students so then both are willing to give dedication for the community, nation and country [3]. Then Civic Education must be able to become a vehicle for citizens' political participation for educators and students in the common interests as citizens in democratic life towards the national goals of Indonesia which always leads to a better life in society, nation and state of Indonesia according to Pancasila, and the 1945 Constitution [4].

If the essence and vision of Civic Education above can be a real guidance and able in realizing Civic Education missions and tasks, then it is not difficult to be able to realizing the ideals and the goals of Civic Education as a vehicle for civic education, as a vehicle for democratic education, and as an Indonesia's national character education. In this case the aim of Civic Education is to build and empowering good and smart citizenship in the sense of: intelligent, faithful and pious, moral and virtuous, democratic, responsible, has a strong commitment, and being participative in the development of citizenship, state and country. In the term of education, civics is a vehicle for education in the framework of nation and character building that enables all citizen to have complete and powerful civic skills and competencies; to become good and smart citizens which also include: civic knowledge, civic disposition, civic skills, civic confidence, civic commitment, civic competence; which as a whole can be used to create a civic culture with a good moral and dignified (humanist, holistic, and religious) [5].

The problem is whether of the Civic Education practice in university, especially at the Ganesha Education University has carried out the Civic Education mission as above [6]. The results of the preliminary study did show that most of the Civic Education lecturers or educators at this institution were indeed lecturers in the Law and Civic Education Department, except for 4 people who came from the Primary Teacher Education Department. It is believed that all Civic Education lecturers have a minimum provision of training and competence in carrying out and realizing the essence, the vision and missions (sociopedagogical, socio-academic, and socio-cultural) to form smart and good citizenship. However, it is known that the higher education backgrounds of lecturers, the value orientation, and their commitment vary considerably. Beside of that, there is no evaluation study effort on how effective the influence of the background and competence of the Civic Education course lecturers on the implementation of the essence, the vision and mission of Civic Education in terms of socio-pedagogical, socio-academic, and socio-cultural to form smart and good citizenship until now. So in this case, we believed that this research is very important to do in order to know the level of understanding of Undiksha students about the essence of Civic Education in implantation the socio-pedagogical, socio-academic, and sociocultural mission to form good and smart citizenship. 


\section{Methods}

This research uses a survey method, the focus of this research is the level of student's understanding about the nature of Civic Education in carrying out the socio-pedagogical, socio-academic and socio-cultural missions in order to form good and smart Indonesian citizens. Whole research was conducted at Undiksha, especially in the departments that offer civics courses in the even semester of the 2019/2020 academic year.

The main data collection technique that used in this study is by providing multiple choice objective tests to determine student understanding about the nature of citizenship education in carrying out the socio-pedagogical, socio-academic, and socio-cultural missions in order to form good and smart citizenship. The data collection in this research is mostly descriptive quantitative which supported by the descriptions of qualitative data from observations and interviews. The data processing procedure is carried out in the following steps: (1) giving an objective test, (2) scoring (3) descriptive statistical analysis, and (4) describing the data [7].

\section{Results and Discussion}

Based on the given test to Undiksha students about the nature of citizenship education in carrying out the socio-pedagogical, socio-academic, and socio-cultural missions to form good and smart citizens showed that the average score of is 64,98 . That score indicates that the level of student understanding about the nature of citizenship education in carrying out the socio-pedagogical, socio-academic, and socio-cultural missions to form good and smart citizens is not yet maximal.

The average score indicates that the level of students understanding about Civic Education is not maximal in carrying out the socio-pedagogical, socio-academic, and sociocultural missions to form good and smart citizens. It can be proven based on the score obtained, it was 64.98. In general, the level of students understanding is described as follows; there are $14.19 \%$ of students who categorized in red zone level of understanding, that classified a very bad category, with scores from 10 to 49 ; there are $19.35 \%$ of students who categorized in orange zone level of understanding, that classified as a bad category, with scores from 50 to 59 ; there are $27.1 \%$ of students who categorized in yellow zone level of understanding, that classified as a normal category, with scores from 60 to 69 ; there are $23.23 \%$ of students who categorized in green zone level of understanding, that classified as a good category, with scores from 70 to 79 ; and there rest $16,13 \%$ of students who categorized in blue zone with a very good score.

Table 1. Distribution Frequency of Student Understanding about the Essence of Civic Education

\begin{tabular}{|c|c|c|c|c|c|c|c|}
\hline No & Categories & \multicolumn{2}{|c|}{ Interval } & \multirow{2}{*}{$\begin{array}{r}\text { Frequency } \\
7\end{array}$} & \multirow{2}{*}{$\begin{array}{r}\begin{array}{l}\text { Relative } \\
\text { Frequency \% }\end{array} \\
4.52\end{array}$} & \multirow{2}{*}{$\begin{array}{l}\begin{array}{l}\text { Cumulative } \\
\text { Frequency \% }\end{array} \\
4.52\end{array}$} & \multirow{2}{*}{$\begin{array}{r}\text { Percentage } \\
4.52\end{array}$} \\
\hline 1 & Very Bad & 30 & 39 & & & & \\
\hline 2 & Very Bad & 10 & 49 & 15 & 9.68 & 14.19 & 14.19 \\
\hline 3 & $\mathrm{Bad}$ & 50 & 59 & 30 & 19.35 & 33.55 & 19.35 \\
\hline 4 & Normal & 60 & 69 & 42 & 27.10 & 60.65 & 27.10 \\
\hline 5 & Good & 70 & 79 & 36 & 23.23 & 83.87 & 23.23 \\
\hline 6 & Very good & 80 & 89 & 16 & 10.32 & 94.19 & 10.32 \\
\hline \multirow[t]{2}{*}{7} & Very good & 90 & 100 & 9 & 5.81 & 100 & 5.81 \\
\hline & & & & $\mathrm{N}=155$ & $100 \%$ & $100 \%$ & $100 \%$ \\
\hline
\end{tabular}


The data above shows that the level of student understanding about the Civic Education is not maximal yet in carrying out the socio-pedagogical, socio-academic and socio-cultural missions to form good and smart citizens. From several observations, and analysis of some existing facts, this fact is caused by the following things. Procedurally, civics has an ideal essence, but this essence was not followed by the implementation of civics in accordance with the essence of Civic Education vision, mission, and goals.

The efforts to develop Civic Education learning practices need to be done through a more holistic-humanist-religious and integrated thinking. Civic Education in the future is not sufficient only to develop rationality, and democratic citizens, as like what done in western countries. However, it also needs to develop a vision of faith, quality, and culture at the same time. Civic Education is not only a guide to realizing the socio-pedagogical mission, but also in an integrated manner to realizing the socio-academic, socio-cultural and socio-religious missions. The characteristics of civics learning in general is still colored by the controlled learning of capitalist society ideology that tends to be rational-empirical-materialistic, which shows that there has been a phenomenon of secularization that separates religious affairs from the state, or religious matters with science so that the spirit of education is based on sociocultural values (local genius), meanwhile the religious value in Civic Education is increasingly thin out [8].

Civic Education learning materials which provided for students, and also learned by students was only focus on studying the relationship between citizens and countries with a secular western pattern; it is very rarely discussing the holistic-humanist-religious values that come from local wisdom; people's spiritual culture in real daily life. Civic Education learning in general still uses a conventional approach. This is because the hidden assumption that Civic Education is a knowledge which can be completely transferred from the teacher's mind to the students' mind (one way method) so then the conventional learning model is still applied [9].

The level of students' understanding about socio-pedagogical mission of civics is not maximal. The understanding that being talked about was the understanding about sociopedagogical mission which related to content, subsidence, material, teaching materials and also concerns the processes of education, teaching and training to have seven civic skills. The seven civic skills include: civic knowledge, civic disposition, civic skills, civic confidence, civic commitment, civic competence, and civic culture which were integrated in the ability to think, behave, and act as democratic Indonesia citizens [10].

In accordance with the level of understanding about socio-academic mission, the students should be able to understand civics which functioned for educators and students academically to developed better civic life through various thinking activities, and reflective inquiry on various problems in daily life among society, nation, and states which can be simulated in academic activities. In this case civics supposed to be able to be the reconstruction or social engineering for educators and students in applying the principles of scientific thinking and research, especially in creating and developing a better democratic life in accordance with the stages of participant thinking, social, emotional and student's moral development [11].

The next important topic is socio-cultural mission. Students have not been able to fully understand the essence of Civic Education. Civic Education must be able to be a function for educators, and students so then both of them can serve the society, nation and state. Civic Education must be able to become a vehicle for socio-political participation for educators, 
and students in the common interests of democratic life in order to achieve the national goals of the Indonesian state based on Pancasila and the 1945 Constitution. As a vehicle for sociopolitical participation, Civic Education does not have to be non-governmental organizations, political institutions, and government superstructure institutions. In this case Civic Education has to be a vehicle for political education for citizen which allows every citizen to contribute actively, and being participative. However, Civic Education must also be able to influence, determine, and control the direction of public policies for common interests in the life of society, nation and state in the unitary state of Republic Indonesia based on Pancasila, and 1945 Constitution[12].

The process of education, and teaching as a form of the implementation of its sociopedagogical mission can be carried out in order to master the integrated civic competence. Civic Education must have the aim of developing civic skills in the student subject as a whole, meaningful, and authentic both concerning personal, social, intellectual, academic, and vocational skills. The development of these skills are only possible if civics is able to fully achieve and integrating all individual competencies of students, including civic knowledge, civic disposition, civic skills, civic confidence, civic commitment, and civic competence that are needed in order to build a dignified civic culture, and good Indonesian moral [5].

The practice of learning the all of Civic Education objectives as above can be formulated as follows: 1) students are sensitive to various problems in their environment; 2) students are responsive to the various implications of the problems they identified; 3 ) students are able to solve one of the most crucial problems from the perspective of democratic citizen; 4) students are able to take collective decisions as recommendations regarding relevant public policies; and 5) students are able to communicate and socializing recommended policy proposals through the corridors and instruments of democracy in their environment [2].

To achieve the objectives of Civic Education as a vehicle for achieving its mission in its socio-pedagogical framework then Civic Education learning must be based and oriented towards developing the practice of the life of relations between the country and its citizens. Civics education in Indonesia needs to be facilitated in order to develop from the knowing paradigm that focuses on the mastery of knowledge, to the doing and building paradigm that focuses on practice in order to prepare citizens who are committed to the application and development of the Indonesian nation. The use of the Contextual Teaching Learning model needs and must be implemented in daily life. The approach can be done by a functional approach, and problem-based learning approach. The instructional strategy used in this model and approach basically departs from the essence of inquiry learning strategy, discovery learning, problem solving learning, research-oriented learning, and cooperative learning which been packaged in a Civic Education learning project model [3].

Then, Civic Education as a vehicle for education and teaching in its socio-pedagogical mission will also be effective if the implementation of the assessment process and student learning outcomes is more authentic. It is also necessary to use alternative assessment models that better reflect the application of democratic principles and principles. Therefore, the assessment of the process and learning outcomes of students must be intact, comprehensive, authentic, meaningful, honest, transparent, objective, integrated, educating, empowering, and not judgmental. The use of assessment strategies such as interviews, observations, essay 
writing tests, performance tests, self-assessments, and well-designed portfolios are the main requirements for the achievement of Civic Education learning objectives in realizing its socio-pedagogical mission [9].

On its socio-academic mission, civics must be useful for educators and students. Thus both can develop a better relationship life between the state and citizens academically through various activities of thinking and reflective inquiry on various political, ideological, legal, state administration and general social issues in the social life of society, nation and state. Civics in this case must be a mean of social reconstruction or a mean of social engineering for educators, and students in applying the principles of scientific thinking and research, especially in creating and developing a better national and state life in accordance with the stages of thinking, social, emotional development, and student's moral [12].

In its socio-cultural mission, civics must be useable for educators, and students so then both of them can serve the community, the nation and the state. Moreover civics must be able to become a vehicle for socio-political participation for educators, and students for the common interests of social, national and state life towards the national goals of Indonesia, which is to achieve a better life based on Pancasila and the 1945 Constitution. As a vehicle for socio-political participation, civics does not must become non-governmental organizations, political institutions, and government superstructure institutions. The next concern is civics needs to be the vehicle for political education which allows every citizen to actively give a participative contribution. But the more important thing is civics must particularly influencing, determining, and controlling the direction of public policies for common interests in the life of society, nation and state in the unitary state of Republic Indonesia based on Pancasila, and the 1945 Constitution[5].

\section{Conclusions}

The level of students' understanding about the nature of civics in carrying out the sociopedagogical, socio-academic, and socio-cultural mission to form a good and smart citizen is at a value of 64.98 which classified as normal category, or not maximal yet. In general, the level of students' understanding is described as follows; as many as $14.19 \%$ of students whose level of understanding was in the very low category with valuesranging from 10 to 49 ; then $19.35 \%$ of students have a level of understanding in the low category with a score from 50 to 59 . In the normal category there are $27.1 \%$ of students with an interval of score from 60 to 69 . Furthermore, at the interval of scoresfrom 80 to 89 there are $23.23 \%$ of students which are classified in the high category, and the rest $16.13 \%$ of students have an understanding level that classified in the very high category of scores. The efforts to improve students' understanding about the nature of Civic Education in carrying out the socio-pedagogical, socio-academic and socio-cultural missions to form good and smart citizens can be taken from the implementation of Civic Education mission. 


\section{References}

[1] U. S. Winataputra, "Posisi Akademik Pendidikan Kewarganegaraan (PKn) dan Muatan/Mata Pelajaran Pendidikan Pancasila dan Kewarganegaraan (PPKn) dalam Konteks Sistem Pendidikan Nasional," J. Moral Kemasyarakatan, vol. 1, no. 1, pp. 15-36, 2016, [Online]. Available: http://ejournal.unikama.ac.id/index.php/JMK/article/view/1184.

[2] U. S. Winataputra, "Jati diri Pendidikan Kewarganegaraan sebagai Wahana Sistemik Pendidikan Demokrasi (Suatu Kajian Konseptual dalam Konteks Pendidikan IPS). (Disertasi),” Universitas Pendidikan Indonesia, 2001.

[3] M. AR, "The New Paradigm of Civic Education and its Implementation in a CompetencyBased Curriculum (in Bahasa)," J. Civ. Media Kaji. Kewarganegaraan, vol. Vol 1, No, pp. 2941, 2004, [Online]. Available: https://journal.uny.ac.id/index.php/civics/article/view/5671.

[4] A. P. Wibowo and M. Wahono, "Civic Education: a Concrete Effort to Study Multiculturalism in Indonesia in Bahasa)," J. Civ. Media Kaji. Kewarganegaraan, vol. Volume 14, pp. 196-205, 2017.

[5] Sukadi, D. B. Sanjaya, and I. W. Kertih, "BELAJAR DAN PEMBELAJARAN PKN SD SEBAGAI YADNYA DALAM RANGKA PERWUJUDAN DHARMA AGAMA DAN DHARMA NEGARA BERBASIS KONSTRUKTIVISME," J. Pendidik. dan Pengajaran, vol. Vol 42, No, 2009, doi: http://dx.doi.org/10.23887/jppundiksha.v42i3\%20Okt.1757.

[6] I. W. Lasmawan, "Strategies for Improving the Quality of Education and Performance of Elementary School Teachers in Supporting the Implementation of Competency-Based Curriculum (Case Study in the Area of the Head of the Branch Office of the National Education Office, Te," J. Pendidik. dan Pengajaran, vol. Vol 42, No, pp. 1-10, 2009, [Online]. Available: https://ejournal.undiksha.ac.id/index.php/JPP/article/view/1735.

[7] A. Suharsimi, "Prosedur Penelitian: Suatu Pendekatan Praktik (Edisi Revisi)," Rineka Cipta, 2010.

[8] P. Widiatmaka, "Civic Education Constraints in Building the Character of Students in the Learning Process (in Bahasa)," J. Civ. Media Kaji. Kewarganegaraan, vol. Vol 13, No, pp. 188-198, 2016, [Online]. Available: https://journal.uny.ac.id/index.php/civics/article/view/12743/pdf.

[9] A. Hasanah, J. Indrawadi, and M. Montessori, "Learning Civic Education (PPKn) in disadvantaged areas (in Bahasa)," J. Moral Civ. Educ., vol. Volume 4 N, pp. 69-77, 2020, [Online]. Available: http://jmce.ppj.unp.ac.id/index.php/JMCE/article/view/223.

[10] Riyadi, S. M. Purwaningsih, and A. Suprijono, "Challenges to Create a Pluralism Education amid the Battle of Democracy and Theocracy in Indonesia," in Advances in Social Science, Education and Humanities Research, volume 383; 2nd International Conference on Social Science (ICSS 2019), 2019, pp. 357-361.

[11] M. Murdiono, Suyato, E. N. Rahmawati, and M. A. Aziz, "Developing an Android-Based Mobile Application for Civic Education Learning,” Int. J. Interact. Mob. Technol., vol. Vol 14, No, pp. 180-193, 2020, [Online]. Available: https://www.online-journals.org/index.php/i$\mathrm{jim} /$ article/view/14967/7879.

[12] M. Murdiono, "CITIZENSION EDUCATION TO BUILD GLOBAL INSIGHTS FROM YOUNG CITIZENS (in Bahasa)," J. Cakrawala Pendidik., vol. XXXIII, NO, pp. 349-357, 2014, [Online]. Available: https://journal.uny.ac.id/index.php/cp/article/view/2379. 